\title{
Production and Technology of Iron and Steel in Japan during 1999
}

\author{
Mutsumi OHJI
}

Chief of Production and Technology Division, The Iron and Steel Institute of Japan, Otemachi,Chiyoda-ku, Tokyo 100-0004 Japan.

\section{Economic Circumstance of the Iron and Steel Industry}

The confusion triggered by the financial crisis of the Southeast Asian economy came to an end and entered a recovery phase, as the countries involved worked hard to avoid the worst outcome. Also, the American economy, although its bubble-like heat remains a source of concern, maintained a high level over long period. The Japanese economy, which marked two years consecutive negative growth, still suffered from depressed facilities investment as well as personal consumption. However, it seemed that the bottom had been reached, as the Japanese Government supported large-scale investment to public works through "Emergency Economic Measures," and as the private companies' engaged in restructuring for the sake of their survival.

However, looking at consumption, complete unemployment rate was 3.17 million workers or $4.7 \%$, which was extremely high for Japanese economy in which fluidity of work force tends to be low. Thus, consumption in personal infrastructures such as homes and automobiles remained at low level. For investment, the companies maintained conservative stance in facilities investment due to the existence of large gap in supply and demand as well as high yen rate, and therefore, the facilities investment of private companies failed to ride the road to recovery.
In such environment, the demand for domestic iron and steel remained very low. However, due to increase of direct demand in large-scale public works and recovery of exports to Southeast Asia, crude steel production in 1999 was 94.2 million tons, a slight increase of about 0.65 million tons or about $0.7 \%$ compared to previous year. Yet, this was second lowest record since 1971 (88.56 million tons).

For the shipment of hot-rolled mild steel products, domestic-use products was 54.86 million tons, which was decrease of about 0.92 million tons compared to previous year, and export products was 17.10 million tons, which was increase of 0.36 million tons or $2 \%$. Total shipment was 72.32 million tons or $0.8 \%$ decrease. Seen by order, slight recovery was seen in construction due to public works investment as mentioned before, but recovery of machinery, shipbuilding, and automobile was delayed, and major products including heavy plates, sheets, and shapes declined. Also, excluding hot-rolled wide strips which performed well in export, production of all products was below the previous year performance, and the production of hotrolled steel was 73.28 million tons or $0.1 \%$ decrease.

The shipment of hot-rolled special steel products declined to 14.22 million tons or $3.7 \%$ decrease compared to previous year, which was worse than mild steel products.

For the export of all iron and steel products in 1999, the volume for the United States decreased sharply due to antidumping claims, but due to the economic recovery of

Table 1. Transition of iron, steel and steel main goods production. (unit:1 000 tons)

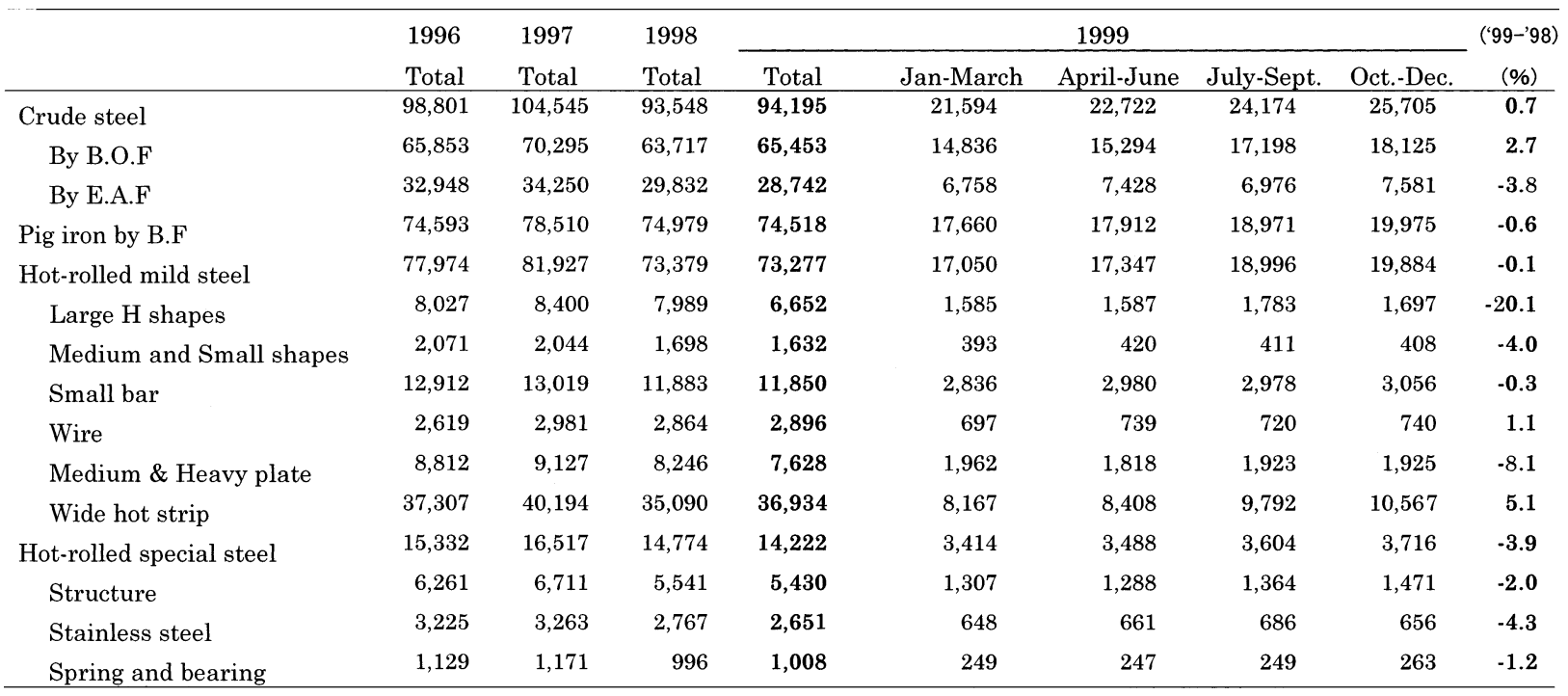

Source: The Japan Iron and Steel Federation 


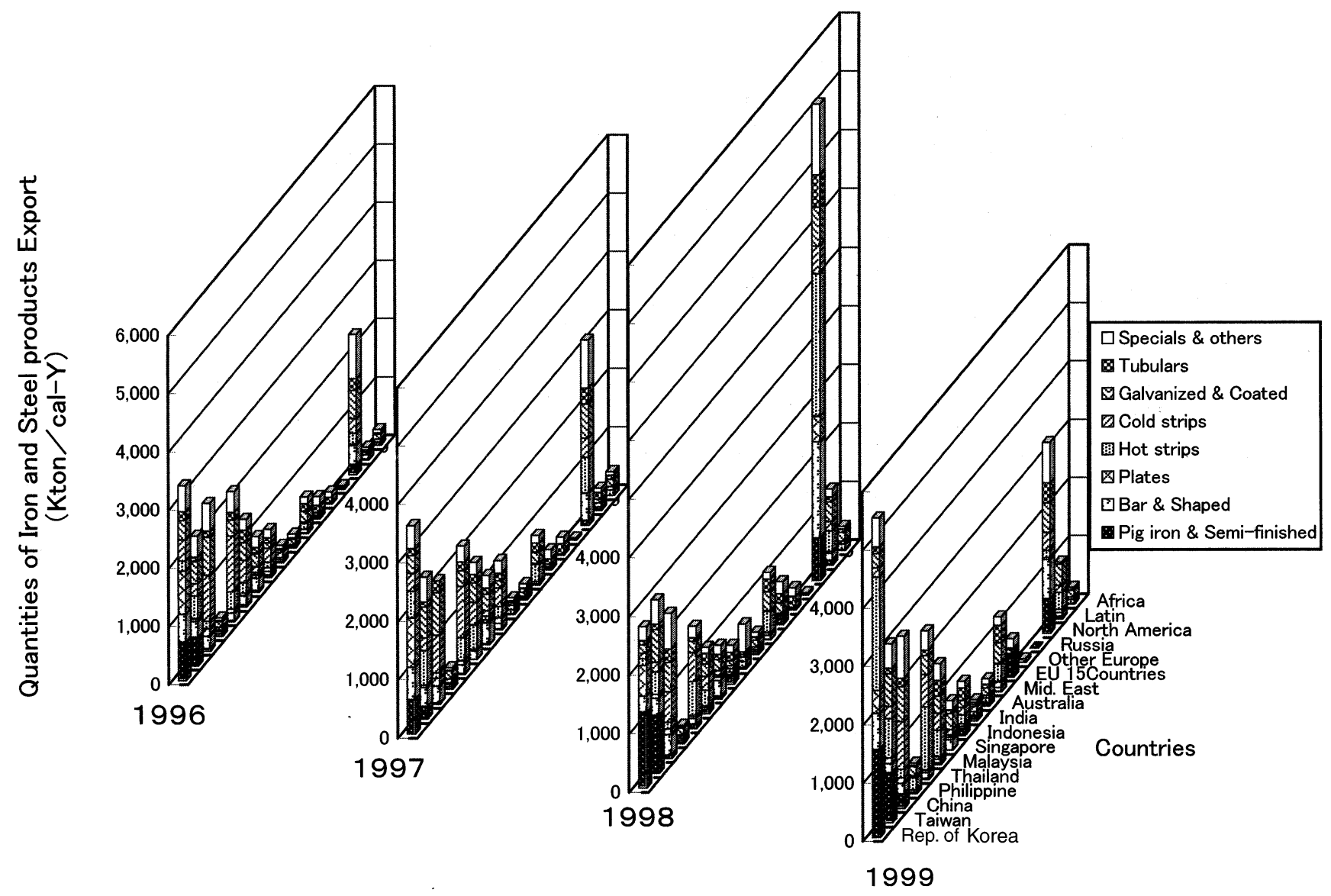

Fig. 1. Exported iron and steel products from Japan. 1999.

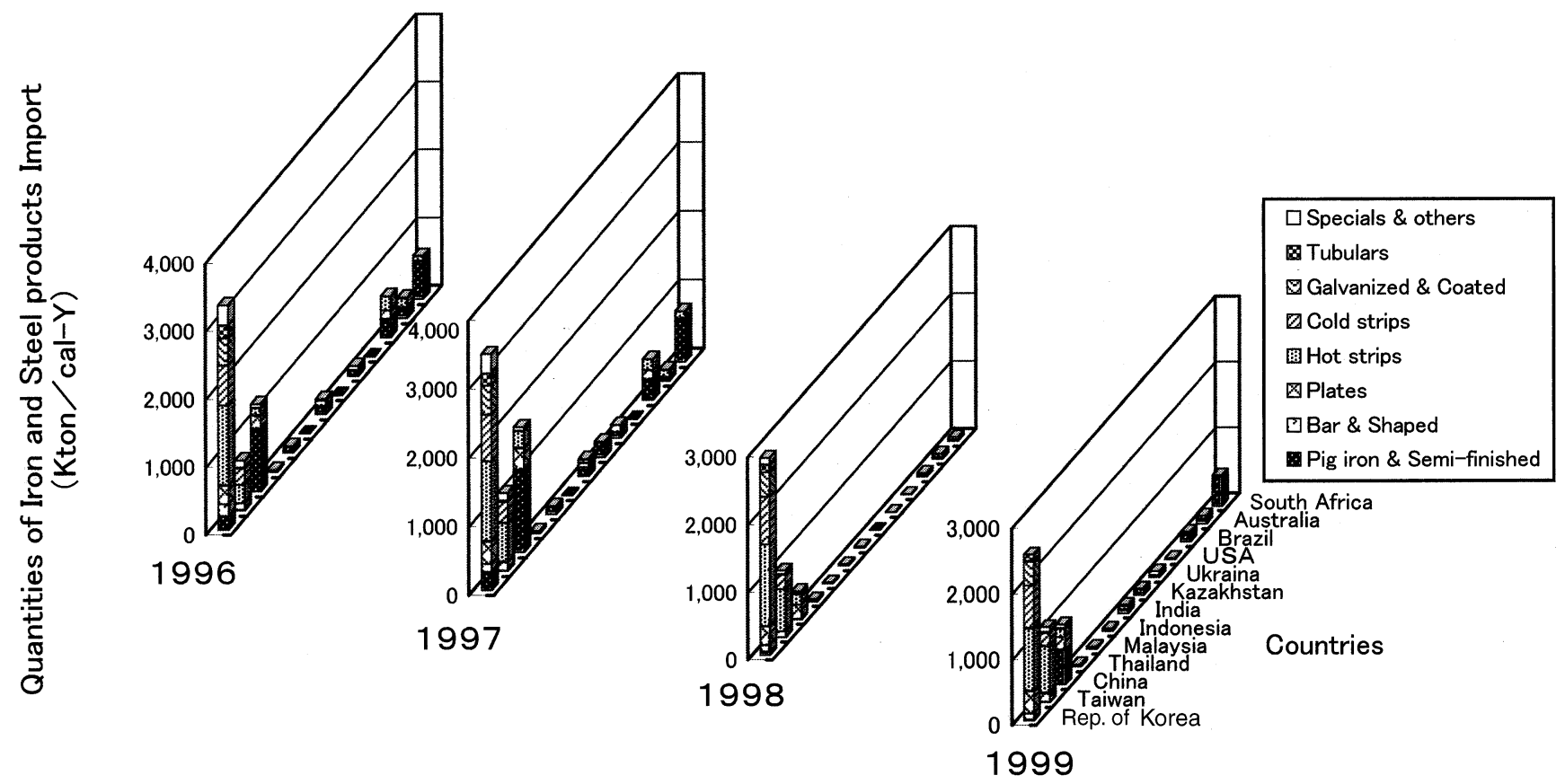

Fig. 2. Imported iron and steel products in Japan. 1999.

ASEAN, Korea, and China, it was higher compared to the levels of recent years. It was about 28.21 million tons or 0.57 million tons increase compared to previous year, which was a good year overall. By products, export to Southeast Asia including Korea and Taiwan of pig iron and semi-finished products increased greatly to about 2.2 mil- lion tons, which was twice compared to previous year. For mild steel products, export of cold-rolled thin sheets and galvanized steel sheets recovered, while $\mathrm{H}$-shapes and medium and heavy plates, which grew rapidly previous year, declined.

Total import of iron and steel products in 1999 was about 
6.48 million tons or 0.15 million tons decrease compared to previous year. Although this was decrease following the previous year, combined import from Korea and Taiwan was over $75 \%$ and maintained a stable share.

The number of employees working in the iron and steel industry was 202058 as of December 1999. This was decrease of about 12000 employees or $5.7 \%$ decrease compared to end of previous year. This surpassed previous year's $5.4 \%$ decrease, and decrease surpassing 5\% annual rate continued for 7 years since 1994. The particulars were: $7.0 \%$ decrease occurred in iron and steel, $3.7 \%$ decrease in processing, and $3.4 \%$ decrease in other related fields.

In raw materials, import of iron ore and coking coal increased slightly, but remained near the annual average level.

In such environment, the companies' investment in iron and steel remained low, and there were no major investments except for rewinding of blast furnaces. However, some companies actively worked on separation of divisions into subordinate companies as well as creation of business units. There were also movements toward intercorporate cooperation in certain product categories.

\section{Technology and Facility}

\subsection{Ironmaking}

Pig iron production in 1999 was 74.52 million tons or $0.6 \%$ decrease compared to previous year. Average pig iron productivity in 1999 was $1.83 \mathrm{t} / \mathrm{m}^{3}$ per day, which was decrease from $1.90 \mathrm{t} / \mathrm{m}^{3}$ in previous year.

In Chiba No. 5 BF, Kawasaki Steel Corp., the production flexibility of the lower part of the blast furnace was improved by establishing stable operation technology with ultra low pig iron productivity of around $1.0 \mathrm{t} / \mathrm{m}^{3}$ per day, with main emphasis on recovery of blast furnace gas, for 7 months from December 1998. Mizushima No. 2 BF, Kawasaki Steel Corp. achieved the record for continuous operation of 7587 days from March 20, 1979 to December 27,1999 , and became the blast furnace with longest lifespan in the world. Also, this blast furnace continues to break its own record, aiming for 25 years continuous operation (see Topics). The record until then was 7586 days of Chiba No. 6 BF, Kawasaki Steel Corp.
For the volume of pulverized coal injection (PCI), as shown in Fig. 3, the PCI rate in 1999 was average $132.9 \mathrm{~kg} / \mathrm{t}$, which was increase of $2.5 \%$ compared to previous year. All companies spent effort in increasing the PCI rate.

Keihin No. 1 BF, NKK Corp. attempted reduction in raw material cost by installing new coke loading device to load cokes in the center of the blast furnace to maintain permeability.

In sintered ore production process, Kakogawa Works, Kobe Steel, Ltd. installed in the sintering machine, a segregation maximizing type raw material feeder using roller feeder to stabilize loading and to maximize segregation of raw materials. Chiba Works, Kawasaki Steel Corp. installed a raw material feeder that used magnet, and the company completed installation of magnetic raw material feeders to all sintering machines. In the No. 1 and 2 sintering machines of Nagoya Works, Nippon Steel Corp., electric dust collector was eliminated, and commenced operation of sinter exhaust gas treatment facility where both desulfurization and dust removal of main sinter exhaust gas were accomplished with moving bed of activated carbon, for first time in the world.

In No. 5 coke oven of Chiba Works, Kawasaki Steel Corp., low expansion molten silica, a new material, was used for four flue bricks from the oven mouth to increase the oven lifespan, and by employing new furnace construction method, bricklaying technology for oven mouth bricks was established, so work could be completed in 14 days, whereas 2 months were required with conventional method. Sumitomo Metal Industries, Ltd., introduced ceramic welding machine for coke oven wall in all coke ovens of Wakayama and Kashima Works and conducted repairs on chips and cracks.

In resource recycling, Keihin and Fukuyama Works, NKK Corp. were in the process of constructing plants which included facilities for conversion of blast furnace materials, so general waste plastic including vinyl chloride could be utilized, and for injection of such material into the blast furnace. When this plant is completed, NKK's capacity for converting plastic for blast furnace material will reach 100000 tons per year. Also, to utilize high concentra-

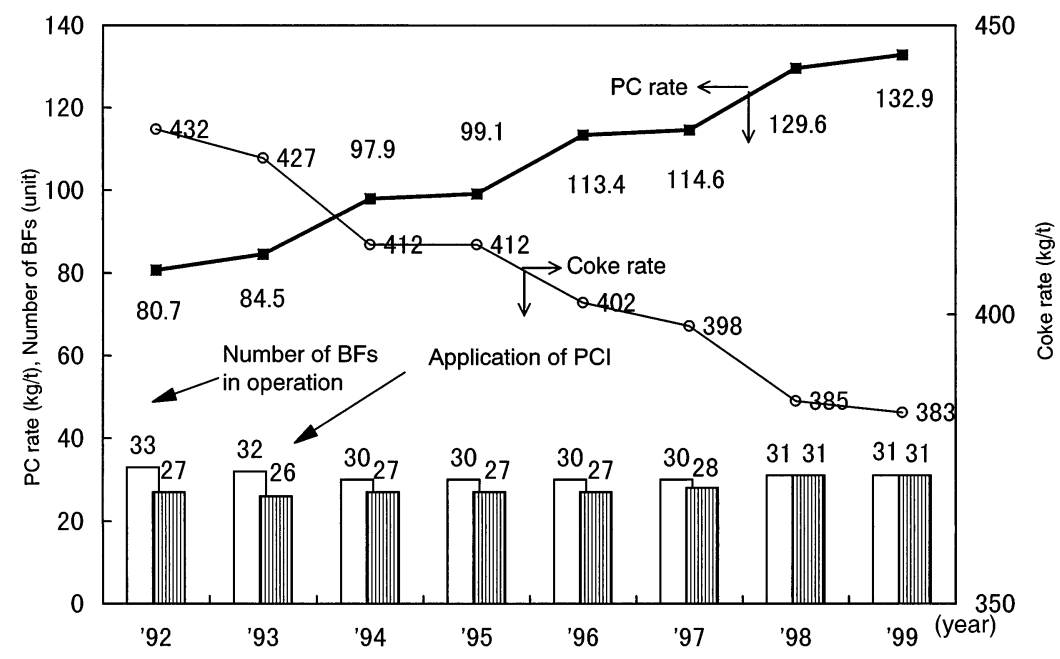

Fig. 3. Increase in Pulverized coal rate injected into blast furnace in Japan. Source: The Japan Iron and Steel Federation. 
Table 2. Operation performance of converter.

\begin{tabular}{lcccccccc}
\hline & 1996 & 1997 & 1998 & \multicolumn{3}{c}{1999} & 1999 \\
& Average & Average & Average & Jan.-March & April-June & July-Sept. & Oct.-Dec. & Average \\
\hline Productivity index per steelmaking hour* & 102 & 104 & 104 & 104 & 104 & 107 & 106 & 105 \\
Steelmaking time index per tap to tap* & 101 & 100 & 98 & 98 & 99 & 97 & 99 & 98 \\
Pig iron mixing ratio(\%) & 93.3 & 92.5 & 95.5 & 96.2 & 95.4 & 93.4 & 93.4 & 93.6 \\
Hot metal mixing ratio(\%) & 92.6 & 91.6 & 94.2 & 95.1 & 94.2 & 91.3 & 91.2 & 92.8 \\
Oxygen consumption $\left(\mathrm{Nm}^{3} / \mathrm{t}\right)$ & 58.7 & 58.7 & 59.2 & 61.4 & 60.6 & 60.4 & 59.4 & 60.4 \\
Ratio of continuous cast steel(\%) & 98.9 & 99.1 & 99.2 & 99.2 & 99.3 & 99.3 & 99.3 & 99.3 \\
Ratio of vacuum treated steel(\%) & 61.3 & 61.1 & 61.6 & 63.0 & 62.9 & 61.6 & 62.4 & 62.4 \\
\hline
\end{tabular}

* The index is based on the average of 1993-1995,100

Source: The Iron and Steel Federation

Table 3. Operation performance of electric arc furnace.

\begin{tabular}{|c|c|c|c|c|c|c|}
\hline & $\begin{array}{c}1996 \\
\text { Average }\end{array}$ & $\begin{array}{c}1997 \\
\text { Average }\end{array}$ & $\begin{array}{c}1998 \\
\text { Average }\end{array}$ & $\begin{array}{c}1999 \\
\text { Jan.-June }\end{array}$ & $\begin{array}{c}1999 \\
\text { July-Dec. }\end{array}$ & $\begin{array}{c}1999 \\
\text { Average }\end{array}$ \\
\hline Productivity index per steelmaking hour* & 110 & 114 & 116 & 105 & 105 & 105 \\
\hline $\begin{array}{l}\text { Electric power consumption per ton of good ingot } \\
(\mathrm{kWh} / \mathrm{t})\end{array}$ & 396.4 & 400.9 & 402.5 & 407.5 & 406.0 & 406.8 \\
\hline $\begin{array}{l}\text { Oxygen consumption per ton of good ingot } \\
\left(\mathrm{Nm}^{3} / \mathrm{t}\right)\end{array}$ & 24.0 & 24.1 & 22.5 & 20.8 & 20.8 & 20.8 \\
\hline Yield of good ingots $(\%)$ & 91.3 & 91.1 & 91.5 & 91.6 & 91.2 & 91.4 \\
\hline Ratio of good continuously cast steel (\%) & 88.6 & 88.9 & 89.4 & 88.8 & 87.6 & 88.2 \\
\hline Ratio of alloy steel (\%) & 32.0 & 32.6 & 32.3 & 35.0 & 36.8 & 35.9 \\
\hline
\end{tabular}

*The index is based on the average of 1993-1995,100

Source: The Iron and Steel Federation

Table 4. Secondary refined steel ratio and its trends (\%).

\begin{tabular}{clcccc}
\hline & & 1996 & 1997 & 1998 & 1999 \\
\hline Converter & Total secondary refined steel & 80.3 & 79.2 & 79.2 & 80.4 \\
& Vacuum treated steel(out of the above figure) & 61.3 & 61.1 & 61.6 & 62.4 \\
\hline Electric arc furnace & Total secondary refined steel & 87.7 & 91.0 & 92.7 & 92.4 \\
\hline
\end{tabular}

Source: The Iron and Steel Federation

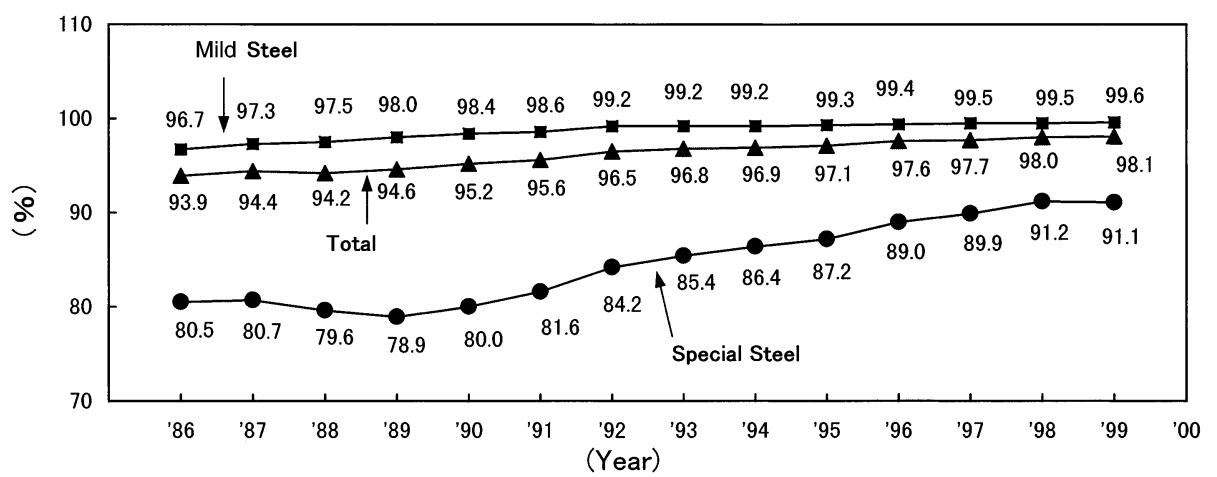

Fig. 4. Change of the ratio of continuous casting production. Source: The Japan Iron and Steel Federation.

tion vinyl chloride, the company was constructing a test furnace for dechlorination process for high concentration vinyl chloride in Keihin Mizue region. Kobe Steel, Ltd. developed a technology for effective dezincing, reduction, and recycling of ironmaking dust, whose main components were iron and carbon, using the FASTMET ${ }^{\circledR}$ process where iron ores were reduced in short time in rotary hearth furnace with coal as reducing agent (see Topics).

\subsection{Steelmaking}

For steelmaking, work performance of converters is shown in Table 2 and performance of electric furnace in Table 3. Although there were no significant change in the figures, decrease of productivity index per steelmaking hour in electric furnace was notable.

Secondary refining ratio (1996-1998) is shown in Table
4. The increased processing rate in electric furnace continued.

While the ratio of continuously cast steel among hotrolled steel products showed slight increase as shown in Fig. 4, there were no major changes for both mild and special steels.

In steelmaking activities by company, all companies worked on process optimization to enhance quality, to reduce cost, and to promote automation and conservation.

Activities of steelmaking plants included the following two cases: commencement of construction of newest steelmaking plant with world's fastest refining time at Wakayama Works, Sumitomo Metal Industries, Ltd. (see Topics); and reinforcement of No. 2 steelmaking plant including strengthening of RH and No. 3 continuous caster at Kashima Works, Sumitomo Metal Industries, Ltd. 
Technological developments in the preliminary processing of hot metal included the following: Muroran and Kimitsu Works, Nippon Steel Corp. established the preliminary hot metal processing method for converter, using stand-by converter as preliminary processing furnace (see Topics); preliminary hot metal processing plant was commenced where all slag after decarbonized treatment at converter were recycled through desiliconization at casting floor, and dephosphorization and desulfurization in torpedo car at Kakogawa Works, Kobe Steel, Ltd.; and total deployment of zero slag steelmaking process at Keihin Works, following Fukuyama Works, NKK Corp.

New activities in continuous casting included the following: introduction of high-speed slab cutting torch (cutting oxygen pressure $30 \mathrm{kgf} / \mathrm{cm}^{2}$ specification) where the cutting speed was 1.5 times the conventional device to No. 3 continuous caster at Chiba Works, Kawasaki Steel Corp.; establishment of high quality, high productivity billet manufacturing line by combining $200 \mathrm{~mm}$ square cross-sectional casting plus compact high pressure mill at Muroran Works, Nippon Steel Corp.; and renovation of tundish maintenance facility which mainly involved introduction of automation and mechanization facilities at No. 3 steelmaking mill, Fukuyama Works, NKK Corp.

Other facilities included the following: introduction of carina dynamo facility which recycled waste heat from converter OG duct cooling at Kashima Works, Sumitomo Metal Industries, Ltd.; improvement of work environment and shortening of work time by introducing automated device and removal of runs which occur at time of slab grinding at Fukuyama Works, NKK Corp.; and commencement of operation of $9 \mathrm{t}$ vacuum induction furnace as well as integration of primary melting plant in order to strengthen the melting capacity of high value-added alloys at Shibukawa Works, Daido Steel Co., Ltd.

In the development of related basic technology, research and development for next generation steelmaking technology which aimed for harmonization with environment (New Steelmaking Project) and development of energy rationalizing metal manufacturing process (Electromagnetic Power Project) were undertaken as national projects at the Japan Research and Development Center for Metals (JRCM). ${ }^{1)}$

For the former project, industrialization FS was implemented for each type of furnace, by conducting series of tests for agitation bath type and packed bed type scrap preheating and melting furnace, following the electric furnace type in 1998, utilizing the integrated system evaluation research plant which was completed in March 1998. This research and development project was completed by end of March 2000.

For the latter project, in addition to the confirmation studies for electromagnetic casting technology using billet commercial-use continuous caster from early 1999, research on application to slab was started in the bench scale continuous caster since end of last year. Also in September, research on fluidity control of hot metal in mold using superconductive magnetic was started using slab bench scale continuous caster.

\subsection{Plate; Pipe and Tube; Section, Wire, and Rod}

For plate, regenerative burner, which was jointly developed with Nihon Furnace, was installed in preheating area of No. 1 heating furnace of plate plant at Keihin Works, NKK Corp., for energy-saving and cutting of heating time (see Topics). At plate 3 mill of Nagoya, Kimitsu, and Oita Works, Nippon Steel Corp., rationalization was conducted in all phases including improvement of control model integrity, expansion of production lot, and reduction of down time, and labor productivity rose to about two times compared to five years ago. Also, at Kimitsu Works, renewal of control system of rolling line was conducted, to achieve one-man operation of rolling by thorough automation using computer control. At Kakogawa Works, Kobe Steel, Ltd., following four improvements were conducted. 1) Establishment of analysis method where quantification of deformation and stress condition of plates could be done using $3 \mathrm{D}$ analysis model of the straightening process of plate roller leveler correction through dinamic explicit. 2) Temperature estimating FF-AGC which does not require proximal gamma ray plate thickness meter was developed, to enable even plate thickness against deformation resistance change during between-path time. 3) For the purpose of improvement of shape quality as well as distribution of heavy plates, multi-functional powerful roller leveler was introduced to enable correction according to deflection during straightening by using hydraulic cylinder for correction of roll deflection. 4) Camber measurement could be accomplished during path by installing camber gauge proximal to finish mill, which enabled precise measurement under poor environmental condition and compact-sizing through laser scanning and photoconductive rod reception.

For wire and rod, renovation of No. 7 wire rod plant was completed at Kobe Works, Kobe Steel, Ltd. The plant included medium water cooling area and finish roller which could handle low temperature rolling, sizing mill which allowed precision rolling, and cooling facilities for adjustment of wire rods. At Muroran Works, Nippon Steel Corp., the work time for roll reassembly was reduced to onethird the conventional time by introducing 3-roll roller, the newest product of Kocks, Germany. Kansai Works, Sumitomo Metal Industries, Ltd. introduced hydraulic $3000 \mathrm{t}$ press for free casting. This facility had latest automatic control where the manipulator and press were synchronized, and precision and speed improved to 80 strokes/minute and standing precision $\pm 1 \mathrm{~mm}$.

For shapes, Kariya Works, Aichi Steel Works, Ltd. developed an original rolling method using existing dual roller, and succeeded in rolling production of stainless H-shapes.

\subsection{Sheets}

\subsubsection{Hot-rolling Process}

At Chiba Works, Kawasaki Steel Corp., high frequency induction sheet bar heating facility commenced operation in No. 3 hot-rolling line, which has endless rolling ability. This improved productivity and stability of quality on the endless rolling, and also made endless rolling of sheets possible, which used to be unsuitable for endless rolling because of the difficult temperature control (ex. high-grade tin

\footnotetext{
1) JRCM NEWS No. 159 (2000.1)
} 


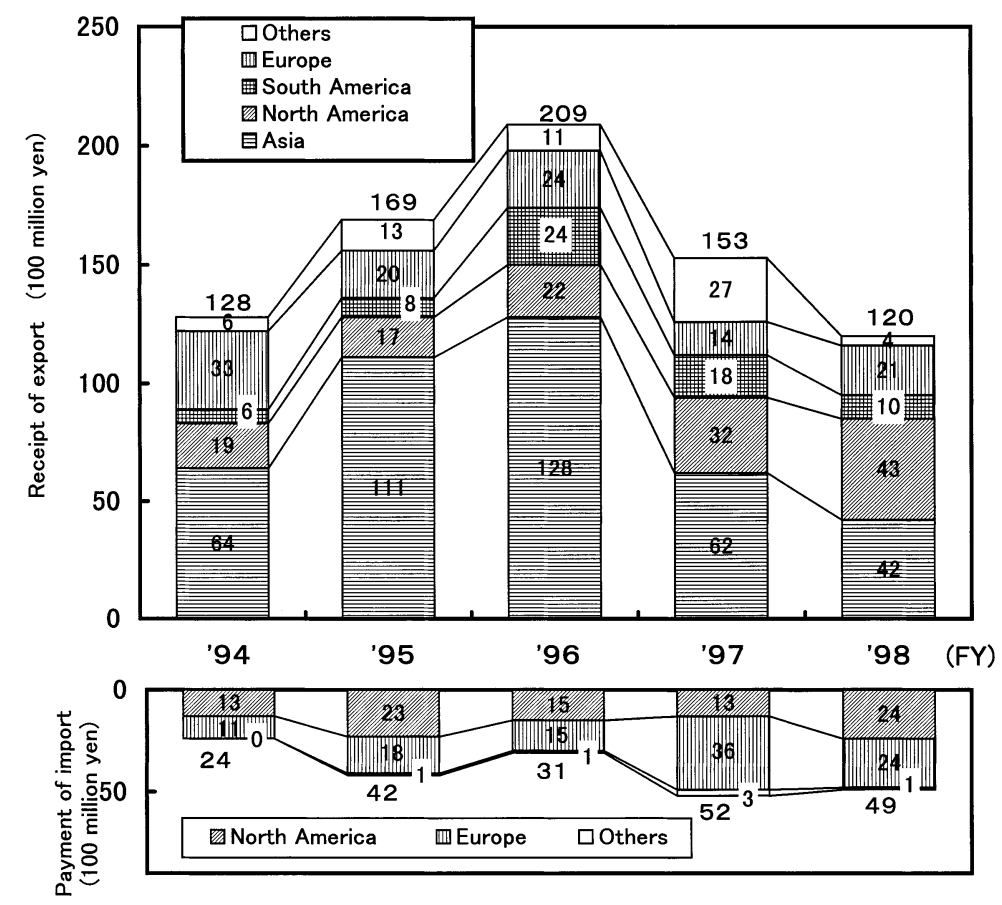

Fig. 5. Balance of technology trade of steel industry.

Source: "Report on the Survey of the Research and Development", Statistics Bureau, Management and Coordination Agency, The Japanese Government.

plates)

At Toyama Works, Nihon Koshuha Steel Co. Ltd., flat sheet rolling facility was installed, and made self-rolling possible on tool steel. Product sizes of up to $75 \mathrm{~mm}$ thickness and $3.5 \mathrm{~mm}$ width can be manufactured.

\subsubsection{Cold-rolling}

At Chita Works, Daido Steel Co., Ltd., another continuous bright annealing furnace for strips was installed in addition to the existing four, to increase heat processing capacity of high grade strip product. This was accomplished to meet the increasing demands of electronic parts which is to be expected in the future.

\subsubsection{Surface Treatment Processes (Miscellaneous)}

Daido Steel Co., Ltd. developed a technology for increasing the tube service life to three times, by reforming the internal of heat dissolution reaction tube at ethylene production plant with plasma powder welding method (PPW). The service life is prolonged because PPW treatment controls the formation of carbonized solids in the internal of the tube.

\subsection{Measurement Control, Plant Maintenance, and Miscellaneous}

For measurement control, Chiba Works, Kawasaki Steel Corp. developed technology for separating the scars detected by camera to harmful scars and noise, to strengthen quality control of acid washed plates with uneven surface property. Also, Chiba and Mizushima Works, Kawasaki Steel Corp. developed a wide surface wave probe for prevention of excessive grinding through minute heat cracks, and improved the roll unit greatly. Technological Development Center of Daido Steel Co., Ltd. installed test device using helical spline method with high torque control precision to conduct realistic fatigue tests for "helical gear."
Tsukiji Works, Daido Steel Co., Ltd. installed a radio darkroom to enable detection of source of harmful radio waves and to simulate countermeasures.

For plant maintenance, Fukuyama Works, NKK Corp. implemented the new plant maintenance system which supported conversion of maintenance personnel to staff tasks, increasing efficiency of integrated work inside and outside the company, and information sharing.

As miscellaneous activities, Technological Development Center of Daido Steel Co., Ltd. developed a hydrogenation shredding technology to shred titanium scraps produced in casting and rolling into sizes usable as scrap material.

\section{Technology Export and Import}

As shown in Fig. 5, the export-import balance of technology trade for the iron and steel industry (Statistics Bureau, Management and Coordination Agency: Report on the Survey of Research and Development), the amount of export against payment and receipt decreased following previous year. The surplus was 7.1 billion yen, which was $30 \%$ decrease compared to 1997 , and this was two year consecutive decease.

The particulars of technological trade in 1999 (number of cases) conducted among the supporting member companies of ISIJ are shown in Table 5. The number of technology export was 93 cases compared to 85 cases in previous year, and there were 2 cases of import. Most of the exports were done to Asia and North America. By technological category, $77 \%$ were shaping, processing and steelmaking.

\section{Research Expenditure}

Figures 6, 7, 8, and 9 show the change in researchers and research expenditure from 1987 to $1997-8$ on companies. 
Table 5. Contents of technology export and technology import. (January 1-December 31,1999).

\begin{tabular}{|c|c|c|c|c|c|c|c|c|}
\hline \multirow{2}{*}{\multicolumn{2}{|c|}{ Field }} & \multicolumn{5}{|c|}{ Area } & \multirow[b]{2}{*}{ Africa } & \multirow[b]{2}{*}{ Total } \\
\hline & & Asia & $\begin{array}{c}\text { North } \\
\text { America }\end{array}$ & $\begin{array}{c}\text { Central \& } \\
\text { South } \\
\text { America } \\
\end{array}$ & Europe & Oceania & & \\
\hline \multirow{22}{*}{$\begin{array}{l}\text { Technical } \\
\text { Export }\end{array}$} & (A) Raw Materials, Ironmaking & & & & & & & \\
\hline & 1) Coke plant operation & 4 & & & & & & 4 \\
\hline & 2) Raw materials handling facilities & 2 & & & & & & 2 \\
\hline & 3) Blast furnace operation & & & 1 & & & & 1 \\
\hline & (B) Steelmaking & & & & & & & \\
\hline & 1) Electric furnace & 1 & 13 & 1 & & & & 15 \\
\hline & 2) Secondary refining & 2 & 2 & & 1 & & & 5 \\
\hline & 3) Continuous casting, ingotmaking & 4 & 4 & 1 & & & & 9 \\
\hline & 4) Auxiliary facilities & 2 & & & & & & 2 \\
\hline & (C) Shaping, Processing & & & & & & & \\
\hline & 1) Bar and wire rod & 1 & 1 & & & 1 & 1 & 4 \\
\hline & 2) Pipe and tube & 3 & 1 & 2 & 2 & 1 & 1 & 10 \\
\hline & 3) Plate & & 1 & & & & & 1 \\
\hline & 4) Sheet & 6 & 6 & & 2 & & 2 & 16 \\
\hline & 5) Surface treatment & 6 & & 1 & & & & 7 \\
\hline & 6) Heat treatment & 1 & & & & & & 1 \\
\hline & 7) Welding Electrode $\cdot$ Parts & 2 & & & & & & 2 \\
\hline & $\begin{array}{l}\text { (E) Iron and Steel Works in General } \\
\text { 1) Feasibility study }\end{array}$ & & & & 3 & & 1 & 4 \\
\hline & 2) General operation guidance & & 1 & 1 & 3 & & & 5 \\
\hline & 3) Maintenance & & & & 1 & & & 1 \\
\hline & 4) Others & 2 & 1 & 1 & & & & 4 \\
\hline & Total & 36 & 30 & 8 & 11 & 3 & 5 & 93 \\
\hline \multirow{2}{*}{$\begin{array}{l}\text { Technical } \\
\text { import }\end{array}$} & $\begin{array}{l}\text { (E) Iron and Steel Works in General } \\
\text { 1) Others }\end{array}$ & 1 & 1 & & & & & 2 \\
\hline & Total & 1 & 1 & & & & & 2 \\
\hline
\end{tabular}

(Coverage: 44 sustaining member companies of ISIJ)

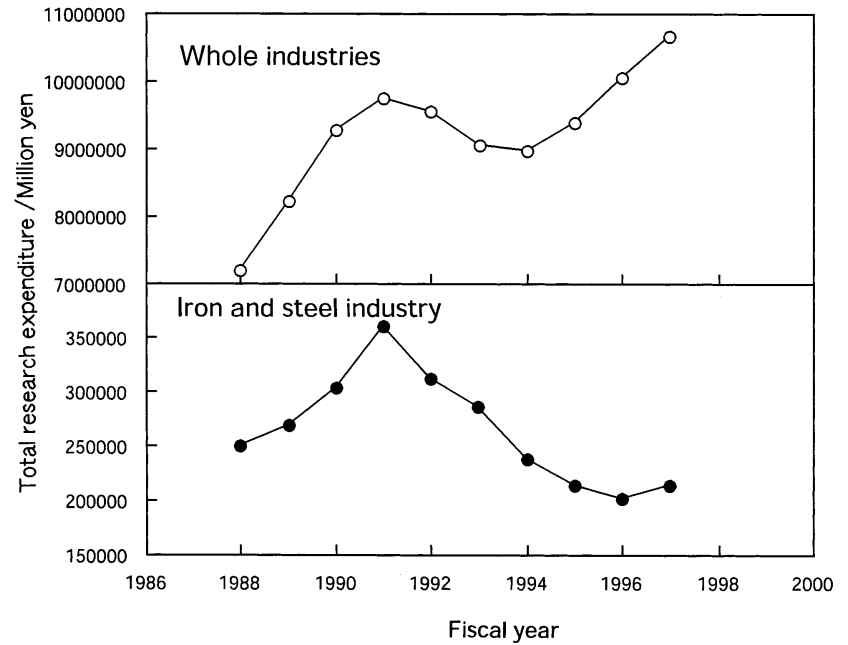

Fig. 6. Trend of total research expenditure.

Source: "Report on the 1998 Survey of the Research and Development", Statistics Bureau, Management and Coordination Agency, The Japanese Government (1998).

For the whole industries, company-use research expenditure and ratio of sales to research expenditure fell after the peak in 1991-2, but shifted to increase from 1994. In iron and steel industry, recovery was slower compared to whole industries, and signs of recovery can be finally observed after

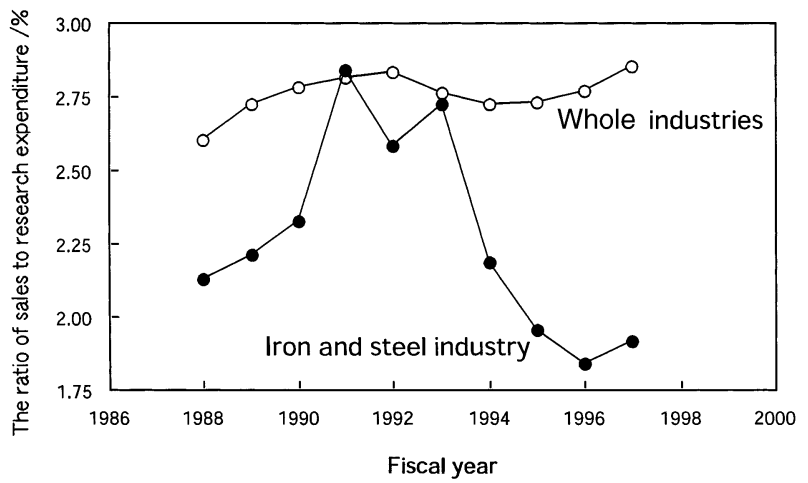

Fig. 7. Trend of the ratio of sales to research expendirture. Source: "Report on the 1998 Survey of the Research and Development", Statistics Bureau, Management and Coordination Agency, The Japanese Government (1998).

1996. Although the number of dedicated researchers increased constantly regardless of research expenditure in whole industries, there seemed to be some linkage to research expenditure in iron and steel industry, and is now at a level quite below the peak period. However, despite some oscillations, the research expenditure for iron and steel industry per 10000 employees followed similar trend as the whole industries. 


\section{Creation of New Technology in ISIJ}

At ISIJ, research activities for production and technology of iron and steel are conducted by the Technical Society, and the organization are listed in Table 6.

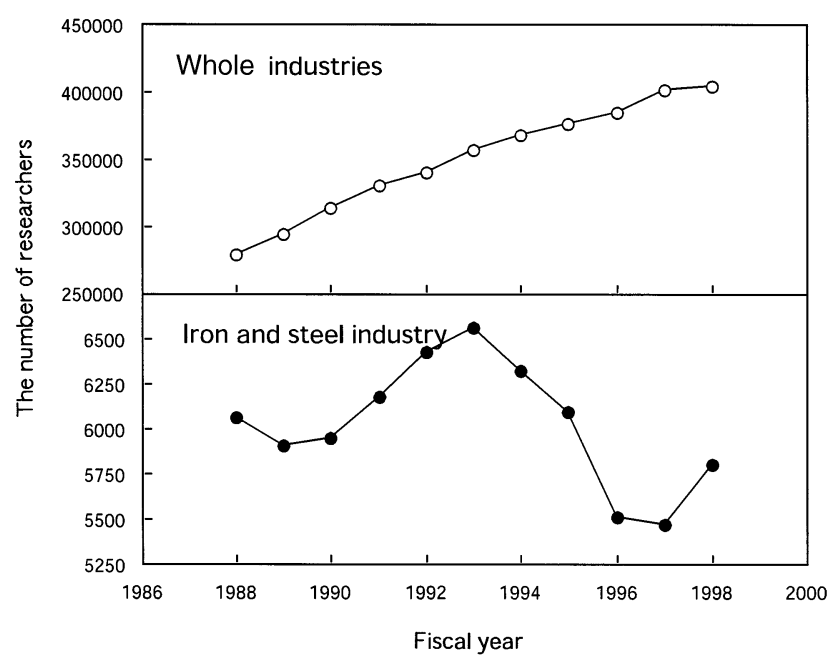

Fig. 8. Trend of the number of researchers.

Source: "Report on the 1998 Survey of the Research and Development", Statistics Bureau, Management and Coordination Agency, The Japanese Government (1998).

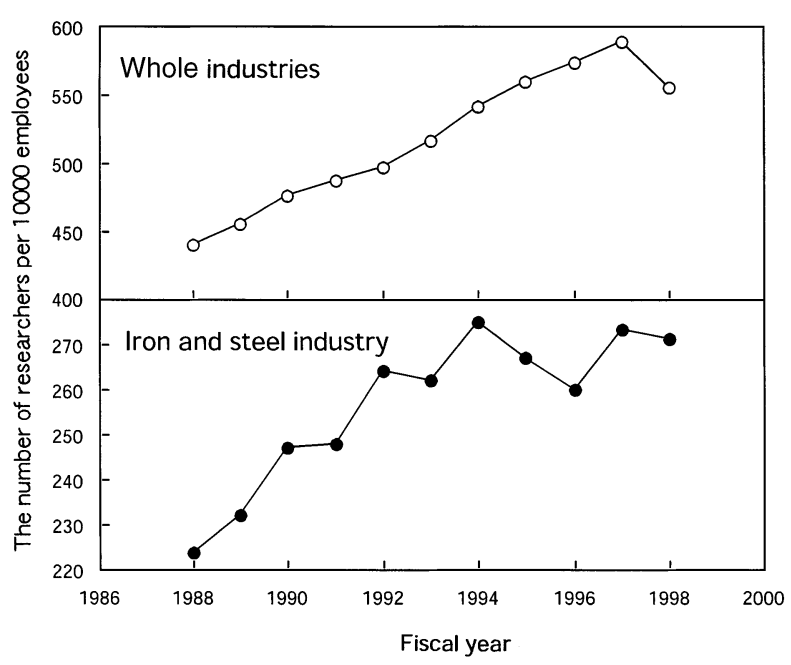

Fig. 9. Trend of the number of researchers per 10000 employees.

Source: "Report on the 1998 Survey of the Research and Development", Statistics Bureau, Management and Coordination Agency, The Japanese Government (1998).
It should also be mentioned that basic research for production and technology of iron and steel and research for excavating new possibilities for the coming generation are done by the Technical Division of Academic Society and the Forums, which are its subordinate organization.

\subsection{Categorized Committees}

At Categorized Committee meetings in 1999FY, currently important themes were taken up as common subjects and particular subjects as shown in Table 7, and active discussions were held.

Participation of university researchers to the committee meetings was promoted, and has become common, to strengthen cooperation between industry and academia for technology creation. More committees planned joint meetings and mutual participation with the Technical Divisions of Academic Society.

The following 14 Technical Investigation Groups were started in 1999FY, and 50 Technical Investigation Groups were active, including those that will complete their activities within the fiscal year.

* Special melting Technology (Special Steel Committee)

* Quality Improvement for Engineering Steel (Special Steel Committee)

* Ingot Casting Technology (Special Steel Committee)

* Quality Improvement and Slag Treatment for Stainless Steel (Special Steel Committee)

* Improvement of Mill Availability - Reduction of Roll Change at Finishing Mill- (Hot Strip Committee)

* Development of Personal Necessary Efficiency at Temper-rolling and Finishing in Cold Rolling Work (Cold Strip Committee)

* Labor Saving and Automatic Control Technology of CGL (Coated Steel Committee)

* Publishing of the $70^{\text {th }}$ Anniversary Issue of Large Section Committee (Large Section Committee)

* Application of 3-D FEM System for Analysis of Steel Bar and Rod Rolling Process (Wire and Rods Committee)

* The Following-up of 3-D FEM Analysis System for Steel Bar and Wire Rod Rolling (Rolling Theory Committee)

* Regular Investigation of Actual Conditions of Mechanical Test Section (Quality Control Committee)

* Uncertainly of Mechanical Test (Quality Control Committee)

* Analysis of Iron and Steel by Use of Less Toxic Reagents (Analysis Technology Committee)

Table 6. Activities of Categorized Committee, Research Group, and Technical Investigation Committee engaging the technology creation in Technical.

\begin{tabular}{|l|l|}
\hline $\begin{array}{c}\text { Technology creation } \\
\text { activities }\end{array}$ & \multicolumn{1}{c|}{ Content of activities } \\
\hline Categorized Committee & $\begin{array}{l}\text { To promote the exchange of technology information concerning iron and steel production with the aim of improving } \\
\text { the level of the conventional technologies, to extract technological tasks in each category and implement researches. } \\
\text { Twenty Committees cover all iron and steel production are established, and engineers and researchers from industry } \\
\text { and university researchers as well, are participating in each Committee. Meeting is held once or twice a year. } \\
\text { "Technical Investigation Groups" that discuss technological problems are established as subordinate organization, and } \\
\text { their activities provide basis for technology creation. }\end{array}$ \\
\hline Research Group & $\begin{array}{l}\text { To conduct the joint research on specific and important subjects for iron and steel industry based on the needs form } \\
\text { industry and seeds from academia. Research Groups that carry out basic researches are working in Academic } \\
\text { Society, and Research Groups that carry out application studies, in Technical Society. The research fund of up to 10 } \\
\text { million yen/year per group is provided for each Group. }\end{array}$ \\
\hline $\begin{array}{l}\text { Technical Investigation } \\
\text { Committee }\end{array}$ & $\begin{array}{l}\text { To make technical examinations and surveys on future development and solution about interdisciplinary } \\
\text { technological problems within the iron and steel industry and with other industries. }\end{array}$ \\
\hline
\end{tabular}


Table 7. Activitiy conditions of the Categorized Committee in 1999FY.

\begin{tabular}{|c|c|}
\hline Committee on & $\begin{array}{c}\text { Common Subject·Particular Subject· Report from Technical Investigation Group } \\
\text { (1):Meeting in spring,(2):Meeting in autumn) }\end{array}$ \\
\hline Ironmaking & (1)Consideration on blast furnace slag design and future issues \\
\hline Coke & (2)Environmental issues in coking plant and future measures \\
\hline Steelmaking & \begin{tabular}{|l} 
(1)Energy-saving in steelmaking \\
(2)Tundish multiple continuous casting technology
\end{tabular} \\
\hline Electric Furnace & $\begin{array}{l}\text { (1) Cost reduction as seen from scrap content } \\
\text { (2)Improvement of productivity }\end{array}$ \\
\hline Special Steel & $\begin{array}{l}\text { (1)Themes for open topic research } \\
\text { (2)Themes for open topic research; Report of Technical Investigation Group }\end{array}$ \\
\hline Heavy Plate & $\begin{array}{l}\text { (1) Survey of plant operation status } \\
\text { (2)Plant maintenance and TPM activity }\end{array}$ \\
\hline Hot strip & $\begin{array}{l}\text { (1) Mostly special lectures } \\
\text { (2)Themes for open topic research; Report of Technical Investigation Group }\end{array}$ \\
\hline Cold strip & $\begin{array}{l}\text { (1) Staff Group - acid washing, rolling, roll shop (case study reports); Foremen Group } \\
\text { use of margin capacity under low operation condition, cost reduction } \\
\text { (2)Plant operation status report; Mostly special lectures }\end{array}$ \\
\hline Coated Steel Sheet & $\begin{array}{l}\text { (1)Energy-saving } \\
\text { (2)Plant operation status report; Mostly special lectures }\end{array}$ \\
\hline Large Section & $\begin{array}{l}\text { (1)Mostly special lectures } \\
\text { (2) Mostly special lectures related to "shape rolling technology" }\end{array}$ \\
\hline Medium and Small Section & $\begin{array}{l}\text { (1)Plant operation status report; Theme research; Mostly special lectures } \\
\text { (2)Themes for open topic research }\end{array}$ \\
\hline Wires and Rods & $\begin{array}{l}\text { (1) Open topic research; Plant operation status report } \\
\text { (2) Common theme - analysis of manufacturing cost and measures for cost reduction; } \\
\text { Foremen theme - safety, environmental, and disaster prevention activities }\end{array}$ \\
\hline Steel Pipes and Tubes & $\begin{array}{l}\text { (1)Mostly special lectures } \\
\text { (2)Reports of Technical Investigation Groups on welding, seamless, and HLP }\end{array}$ \\
\hline Rolling Theory & $\begin{array}{l}\text { (1)Research report } \\
\text { (2)Themes for research }\end{array}$ \\
\hline Heat Economy Technology & (2) Report of Technical Investigation Group \\
\hline Refractories & $\begin{array}{l}\text { (1)Panel discussion "Furnace building, undefined format" } \\
\text { (2)Themes for research }\end{array}$ \\
\hline Control Technology & $\begin{array}{l}\text { (1) Research report; Special session "Current status and future of control modeling," "2 } \\
\text { degrees of freedom PID... its meaning and adjustment method" } \\
\text { (2) Research reports on electricity, measurement, and process control; Mostly special } \\
\text { lectures }\end{array}$ \\
\hline Quality Control & $\begin{array}{l}\text { (1)(Machinery Testing Division) Regular report on work performance; Mostly special lectures } \\
\text { (2)(QAQC) Efficient and effective implementation of ISO9000 }\end{array}$ \\
\hline Analysis Technology & $\begin{array}{l}\text { (1)Report of Technical Investigation Group } \\
\text { (2) Report of Technical Investigation Group }\end{array}$ \\
\hline Plant Engineering & $\begin{array}{l}\text { (1)Maintenance technology for stable blast furnace } \\
\text { 2) Common issue "Case studies for technical investigation on plant aging" }\end{array}$ \\
\hline
\end{tabular}

Table 8. Research Groups in operation.

\begin{tabular}{|l|c|c|}
\hline \multicolumn{1}{|c|}{ Research Group on } & $\begin{array}{c}\text { Activity term } \\
\text { (Fiscal Year) }\end{array}$ & belongings to \\
\hline Enhanced Processing Technology in the Lower Part of Blast Furnace & $1997 \sim 2000$ & Academic Society \\
\hline Modeling of Optical Surface Properties of Steel Plates & $1997 \sim 2000$ & Academic Society \\
\hline Formation Process of Microstructure Due to the Phase Decomposition & $1997 \sim 2000$ & Academic Society \\
\hline High-speed Deformation of Steels for Automotive Use & $1997 \sim 2000$ & Technical Society \\
\hline $\begin{array}{l}\text { Modeling and Optimization of Planning Problems in Steel Industry - large } \\
\text { Scale Complex Systems Approach - }\end{array}$ & $1998 \sim 2001$ & Academic Society \\
\hline Rapid and High Sensitivity Analysis for Steel Production Control & $1998 \sim 2001$ & Academic Society \\
\hline Coke Property & $1998 \sim 2001$ & Technical Society \\
\hline
\end{tabular}

* Mechanical Technology for Reduction of Maintenance Cost and Extension of Mechanical Life on Hot Rolling (Plant Engineering Committee)

\subsection{Research Group}

Six Research Groups were started in 1999FY, and 7 Groups completed their activities. Existing groups are described in Table 8. (Except groups completed in 1999FY) The objectives and results of their activities are described in Table 9.

\subsection{Technical Investigation Committee}

"Technical Investigation Committee on Desirable Steel Materials for Automobiles" commenced phase II activities in 1998FY (scheduled completion in 2000FY). Carried over from previous year, "Technical Investigation Committee on Process Metallurgy and Properties of Modern Structure Steels" ( 1999FY) and "Technical Investigation Committee on Suitable Steel Structure for Inhabitant's Individual Infills" ( 2000FY) were active. 


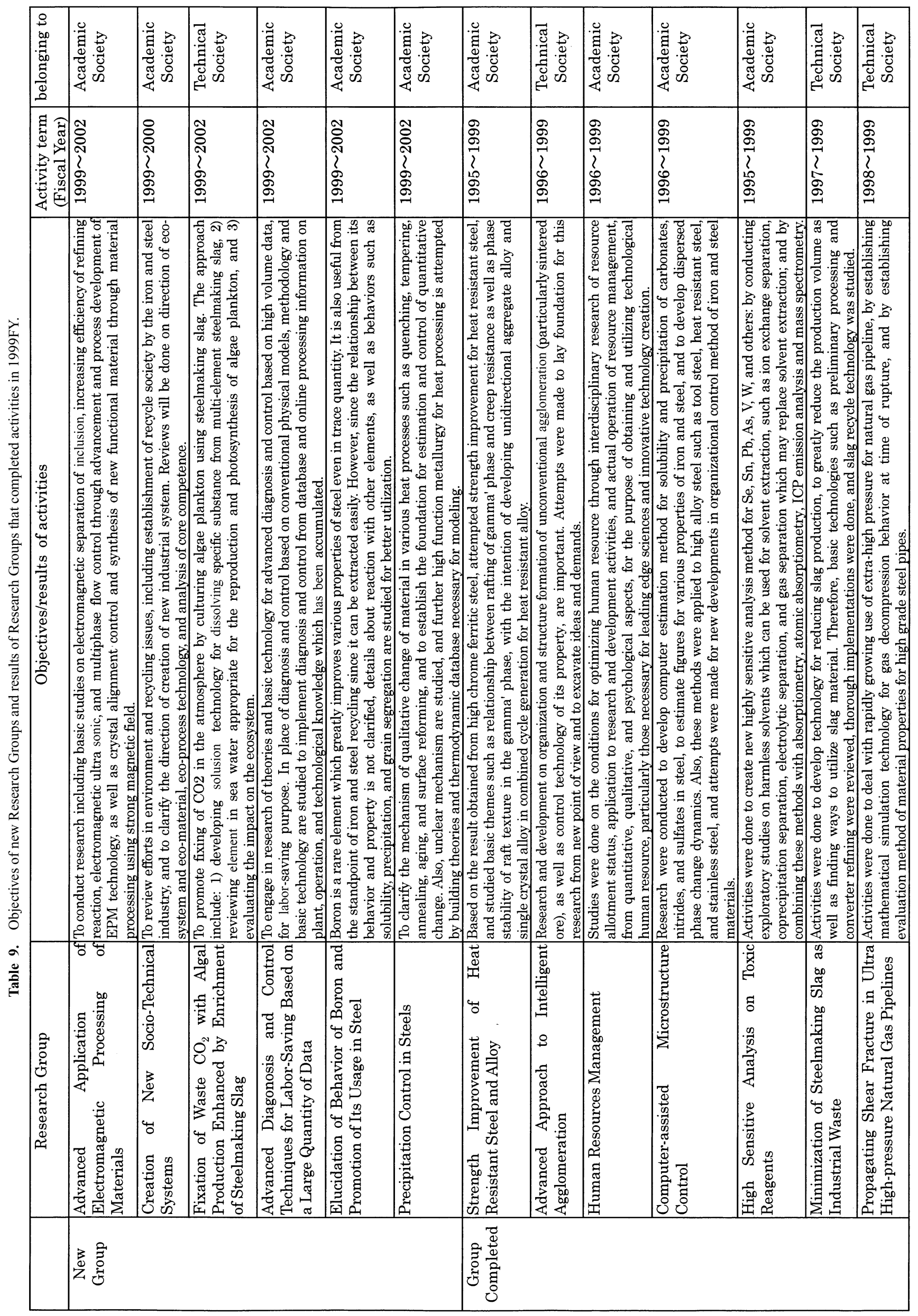




\section{New Iron Source, Ferrous Alloy}

\section{FASTMET $^{\circledR}$ Steel Mill Waste Recycling Plant By Kobe Steel, Ltd.}

Kobe Steel and its subsidiary, Midrex Direct Reduction Corporation, have developed a direct reduction process called the FASTMET ${ }^{\circledR}$ Process which uses iron ore fine and pulverized coal. In this process, the iron ore fine is mixed with the pulverized coal and formed into pellets or briquettes. The pellets or briquettes are fed into a rotary hearth furnace and heated to 1250-1400 degrees C. Under high heat, the pulverized coal acts as a reductant and the iron ore is reduced to metallic iron.

The FASTMET ${ }^{\circledR}$ Process is highly suitable for recycling steel mill waste because it can utilize $\mathrm{BF} / \mathrm{BOF} / \mathrm{EAF}$ dust and mill sludge as the raw material instead of iron ore fine and can recover metallic iron in those wastes efficiently. In addition, high temperature operation and stable pellet/briquette reduction enable the effective recovery of zinc oxide and decomposition of dioxin into a harmless substance.

Kobe Steel has been contracted to construct the first commercial plant (annual capacity: 190000 tons of steel mill waste) using the FASTMET ${ }^{\circledR}$ Process at Nippon Steel. This plant will start up this spring.

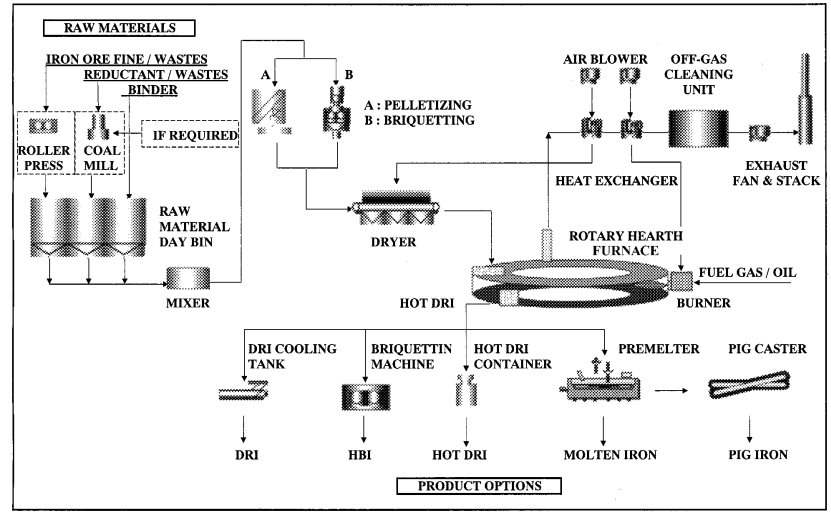

FASTMET ${ }^{\circledR}$ Process Flow.
(1) [Uniform burden descent and stabilization of the furnace condition by optimum distribution control of the charged ore by respective [Mn]\%]

When $[\mathrm{Mn}] \%$ is changed, the blending ratio of several brands of Mn ore is changed greatly, which tends to disturb the gas flow distribution in the furnace and deteriorate permeability. Therefore, a charging control method was developed, in which the distribution of charged materials is changed, using the bell-less device, corresponding to the blending ratio of several brands of Mn ore, and a furnace operation technology which maintains stable burden descent and furnace conditions by uniform gas distribution was established.

(2) [Raw material blending technology and improvement of accuracy in prediction of traveling time in the shaft furnace]

An optimum blending standard, which specifies the selection of raw materials by $[\mathrm{Mn}] \%$ and the blending method, was established based on an analysis of actual furnace operation. This standard, together with stable burden descent, made it possible to obtain stable traveling times by $[\mathrm{Mn}] \%$, which in turn made it possible to standardize the timing of charged material blending changes. In actual operation, the difference between the target $[\mathrm{Mn}] \%$ and actual $[\mathrm{Mn}] \%$ is analyzed to further improve accuracy. The results are fed back to the next blending operation, and fine adjustments are made in the raw material mix and the timing of blending changes.

It has been possible to reduce the difference between the target $[\mathrm{Mn}] \%$ and actual $[\mathrm{Mn}] \%$ to less than $[\mathrm{Mn}] 0.3 \%$ as an average value.

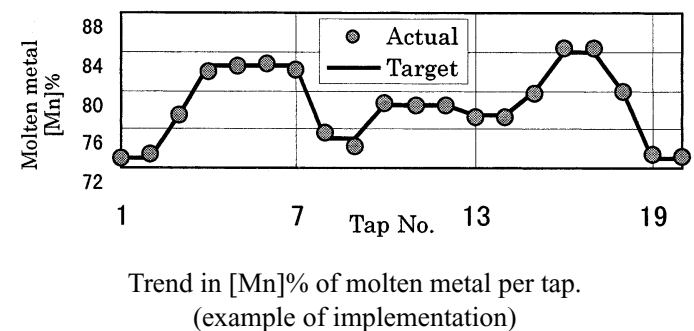

\section{Blast Furnace Operation}

\section{Mizushima Works No. 2 Blast Furnace Sets New World's Record for Continuous Operation By Kawasaki Steel Corp.}

Mizushima Ferroalloy Co., Ltd. produces high carbon ferromanganese using a small scale vertical shaft type furnace (inner volume, $398 \mathrm{~m}^{3}$ ), and produces medium and low carbon ferromanganese by decarburizing the high carbon molten metal from the shaft furnace. In order to respond to the diversification and increasing strictness of users' quality requirements for medium and low carbon ferromanganese in recent years, the company established a production method which makes it possible to smelt molten metal with an $[\mathrm{Mn}]$ content in the range of $70 \sim 84 \%$ to freely selected values, in units of $1 \%$, in each tap (55t/tap) from the shaft furnace. This method has the following two features.
Kawasaki Steel's Mizushima Works No. 2 blast furnace (inner volume: $2857 \mathrm{~m}^{3}$, capacity: $6000 \mathrm{t} / \mathrm{d}$ ) has been in continuous operation since it was blown in for its third campaign in March 1979. On December 27, 1999, No. 2 $\mathrm{BF}$ set a new world's record for blast furnace life, at 7587 days of continuous operation (approximately 20 years, 9 months), breaking the old record of 7586 days held by $4500 \mathrm{~m}^{3}$, capacity: $10000 \mathrm{t} / \mathrm{d}$ ).

Mizushima No. 2 BF also achieved a cumulative production ratio of $14422 \mathrm{t} / \mathrm{m}^{3}$ (as of December 31, 1999), surKawasaki Steel's Chiba Works No. 6 BF (inner volume: 
passing the Japanese record $\left(13385 \mathrm{t} / \mathrm{m}^{3}\right)$ held by Chiba No. $6 \mathrm{BF}$, and is continuing to set new records in this regard.

The factors which determine the life of a blast furnace have conventionally been considered to be the condition of the furnace shaft shell and hearth brick damage. However, long life was achieved at Mizushima No. 2 BF by adapting the following equipment and operational technologies.

1) Furnace shaft shell: From the viewpoint of equipment, the reliability of the stave cooling equipment which protects the shell was greatly enhanced in comparison with the conventional type by technical improvements (KSC type stave), and at present, damage to the stave piping is extremely slight, at $0.7 \%$. From the operational viewpoint, deviations in the burden distribution in the furnace have been reduced by radial and circumferential burden distribution control, making it possible to reduce the thermal load on the furnace body by adjusting the gas flow in the furnace. It has also been possible to maintain a stable furnace condition over the long term by applying a diagnosis system for blast furnace condition.

2) Hearth brick damage: Based on temperature data in the hearth, a model for estimating the profile of the solidified layer in the furnace was developed and is being used to prevent further hearth damage by changing operating conditions.

Plans have been made to maintain stable operation of Mizushima No. 2 BF, aiming at an operating period of 25 years, while continuing to establish new records for blast furnace life and cumulative production ratio.

\section{Converter, Secondary Refining}

\section{Wider Application of Hot Metal Pretreatment by BOF By Nippon Steel Corp.}

The pretreatment for hot metal dephosphorization was developed and commercialized from around 1980 as part of the production process for high-purity steels such as ultralow-phosphorus steel. The application of the pretreatment has since been widened, covering ordinary steels. At present, it is the basic process for steel refining.

In 1982, NSC introduced hot metal dephosphorization in the torpedo-car at Kimitsu Works (and later at Yawata Works), the world's first. In 1986, hot metal dephosphorization in the ladle was commercialized at Oita Works.

In 1989, Nagoya Works started the dephosphorization of all hot metal by BOF. In this process, volume oxygen can be blown in at high speed, utilizing the BOF's large inner capacity which is an intrinsic equipment characteristic, without causing slag slopping or hot metal splashing. Also, strong stirring is possible using vessel-bottom gas injection. As a result, fast dephosphorization in about ten minutes is possible, attaining far higher productivity than by other processes.

Other features of the BOF process are that, since it uses gaseous oxygen, the heat loss is minimum, enabling the use of large quantities steel scrap. This means greater production flexibility and less $\mathrm{CO}_{2}$ emission. Also, it is a process suited to greater slag recycling. Furthermore, dephosphorization is possible even at low slag basicity during opera- tion which leads to the enhanced commercial value of byproduct slag. In other words, the BOF pretreatment is a process well matched to environmental protection purposes.

NSC promotes the wider application of the BOF dephosphorization which requires minimum investment, by increasing the availability of existing BOFs through higher working rates. The process is also in operation at Muroran and Kimitsu Works.

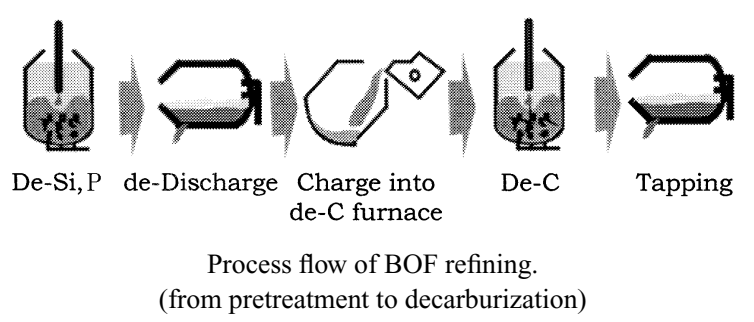

\section{Development of New Type Vacuum Degasser (REDA) By Nippon Steel Corp.}

Recently, the needs for even higher purity, or mass production of, ultralow-carbon steel have intensified in the area of special steels such as stainless steel, not to mention automotive steel sheets. These market needs have been met in the steelmaking process by increasing the decarburization capacity of vacuum secondary refining equipment such as RH-OB, DH and VOD.

NSC's Yawata Works has commercialized a new, highspeed, Revolutionary Degassing Activator (REDA) which combines a large-diameter single snorkel and ladle-bottominjection of Ar gas. With this system, Yawata Works manufactures super-ultralow-carbon steel of less than $10 \mathrm{ppm} \mathrm{C}$ on a stable basis.

Normally, the decarburization reaction at an ultralowcarbon concentration involves a stagnant reaction zone. In this zone, the reaction at the free surface exposed to vacuum is the most important. In REDA, with the use of a largediameter snorkel and gas injection at a great depth, a larger bubble-activated plane can be obtained at the vacuum surface with less gas injection than by other processes, efficiently refining super-ultralow-carbon steel in a short period of time.

Refining functions such as dehydrogenation and inclusion elimination are also improved. REDA has other merits such as lighter skull to the vacuum vessel interior because less gas injection is necessary.

Remodeling the existing degassing facilities to REDA can be implemented at an extremely low investment and in a very short period of time. At NSC, REDA is also installed at Kimitsu Works.

At Yawata Works, it is also applied to refining of stainless steel. Compared to the conventional processes, REDA can reduce $\mathrm{C}+\mathrm{N}$, contributing to the establishment of an efficient, high-purity stainless steel refining process. 


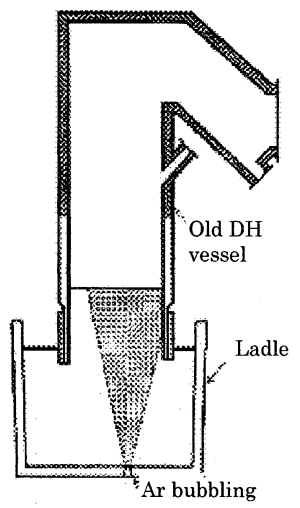

Outline of REDA

\section{New Steelmaking Plant at Wakayama Works By Sumitomo Metal Industries, Ltd.}

Sumitomo Metal Industries started a new melt shop at Wakayama Works which uses Sumitomo's total technology for high productivity and high quality such as the hot metal dephosphorization process with a top and bottom blowing BOF etc.

The new shop consists of two desulfurizing furnaces as $\mathrm{KR}$, a dephosphorizing top and bottom blowing BOF, two decarburizing top and bottom blowing BOFs and two RH vacuum degassers with a lance for top blowing flux.

The main advantages of the new shop are as follows:

(1) Highest-speed decarburization of BOF in the world

(2) $100 \%$ treatment ratio of hot metal dephosphorizing and RH degassing to produce high clean steel with high productivity

(3) First synchronizing operation in the world from BOFs to a seamless-pipe mill through a round caster.

This process can meet the demand for a higher grade seamless pipe in future with high productivity and short delivery.

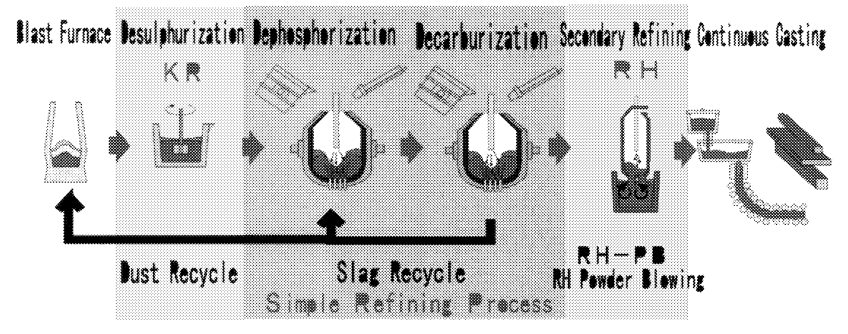

The new melt shop as Sumitomo's Wakayama Works.

\section{Hot-rolling Strip, Plate Steel}

\section{The Environmentally Friendly Regenerative Burner Heating System By NKK Corp.}

NKK and Nihon Furnace Kogyo (NFK) jointly developed the ceramic honeycomb regenerative burner for reconciling ultimate waste heat recovery with extremely low NOx combustion, as an environmentally friendly, new energy saving technology.

This technology is applied to several NKK furnaces, including continuous slab reheating furnace of the NO. 1 Hot
Strip Mill at the Fukuyama Works, which is the first full burner application to a large-scale, hot-rolling reheating furnace in the world.

Conventional heat recovery furnaces are commonly equipped with metal recuperators for pre-heating air in the outlet of the furnaces, but the pre-heated temperature is limited to about $800 \sim 900 \mathrm{~K}$ with a furnace temperature of $1620 \mathrm{~K}$, due to material temperature limitation.

In addition, the pre-heated temperature of air for the ceramic ball type regenerator which has begun to be used in Europe, is limited to about $1270 \mathrm{~K}$ with a furnace temperature of $1620 \mathrm{~K}$, in order to meet the restrictions on NOx emission.

However, by using the compact and high performance ceramic honeycomb-type regenerator, the new technology has resulted in the unit fuel consumption being reduced by $25 \%$, enabling the preheated air to reach a high temperature of $1600 \mathrm{~K}$, nearly the same as that of the furnace.

At the same time, there is a substantial reduction of NOx emissions to $30 \%$ or less of the regulated level by using a technology, which flattens the temperature profile.

This Regenerative Burner Heating System technology is not only applicable to reheating furnaces, but also to thermo-treating furnaces and melting furnaces and other types of furnace.

Furthermore it is not only applicable to the steel industry, but also to the non-ferrous industry as well as automobile, ceramic and food production and chemical industries.

In particular, the technology has been adopted by the national R\&D project titled, "Development of High Performance Industrial Furnaces", as a basic technology.

The technology was field tested in this High Performance Industrial Furnaces Project in the fiscal 1998 and 1999 stages and was proven to be a new energy saving technology that can contribute to a wide range of industries.

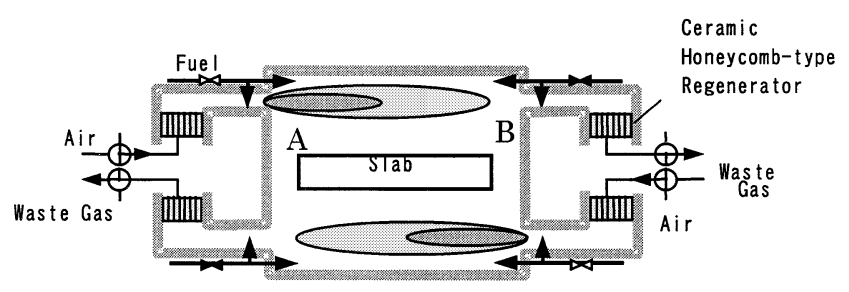

(mutual switching combustion of burner A and B). Regenerative Burner Heating System

\section{Mass Production of New Products at Chiba Works No. 3 Hot Strip Mill By Kawasaki Steel Corp.}

Kawasaki Steel's Chiba Works began operation of a new hot strip mill (No. 3 hot strip mill) in May 1995. The new mill was constructed in order to respond to the needs of customers for improved product accuracy, a wider available size range (particularly for thinner gauge products), and higher product quality. Features of No. 3 hot strip mill include (1) practical application of the world's first "endless rolling" (continuous hot rolling) technology in the hot finishing mill, (2) accompanying high accuracy control functions, and (3) adoption of high rated load, high capacity motors. 
Since startup, various new products which take advantage of the features mentioned above have been developed. In 1999, after matching these products with the needs of customers, various newly developed items won acceptance as commercial products in the marketplace and reached the stage of stable mass production. The main new products which have achieved mass production are as follows:

(1) Ultra-thin black sheets for export with thicknesses under $1.2 \mathrm{~mm}$

(2) Thin gauge wide hot rolled sheet as a substitute for cold rolled sheet (includes hot-dip galvanized steel sheets using this sheet as the mother material)

(3) Thin hot rolled steel sheets of $440 \mathrm{MPa}$ grade for automotive use

(4) Cold rolled sheets with ultra-high r-values

(5) Super HSLA hot rolled steel sheets of 590 780 MPa grade

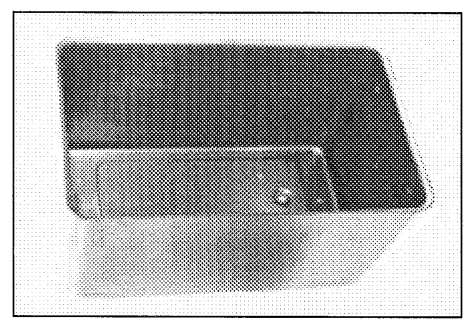

Example of application to rectangular body type formed part $(t=1.2 \mathrm{~mm}) \quad(\mathrm{W} / 400 \mathrm{~mm} \times \mathrm{L} / 250 \mathrm{~mm} \times \mathrm{H} / 250 \mathrm{~mm})$

\section{Extremely-low Carbon Bainite Steel Plate of As- Rolled Type By Kawasaki Steel Corp.}

Kawasaki Steel Corporation has established a technology for producing steel materials with high strength, excellent low temperature toughness, and superior weldability in the as-rolled state, that is, without heat treatment. Using this technology, the company developed extremely-low carbon bainite steel plates of the as-rolled type.

In recent years, steel materials which provide higher strength and toughness than the conventional products, combined with greatly improved weldability, cover a wide range of sizes, and can be produced without heat treatment have been demanded to improve the safety of welded structures, shorten lead times, and reduce costs.

It was no easy matter to meet these requirements, even using the TMCP method as a total technology. However, the adoption of an extremely-low carbon bainite microstructure steel was found to be one method of solving this problem.

This microstructure was realized by reducing the carbon content to below the maximum solubility in ferrite (approximately $0.02 \%$ ), and further, by reducing the transformation temperature to approximately $700^{\circ} \mathrm{C}$ or under by micro-alloying of boron and other elements. The CCT diagram of this extremely-low bainite steel shows a basically uniform bainite structure over a wide range of cooling rates, and as a result, the changes in hardness due to the cooling rate after finish rolling are completely different from those of conventional steels.

First, in the low cooling rate region, the extremely-low carbon bainite microstructure steel shows higher hardness than the conventional steels in spite of its low $\mathrm{C}$ content.
Therefore, it is possible to produce heavy gauge steel products with a low $\mathrm{C}$ content without using heat treatment. On the other hand, in the high cooling rate region, the extremely-low carbon bainite microstructure steel exhibits the opposite tendency, showing lower hardness than the conventional steels. This eliminates the difference in hardness in the surface layer and interior when heavy gauge steel materials are cooled, and also markedly reduces the hardness of the heat-affected zone in welding.

A $570 \mathrm{~N} / \mathrm{mm}^{2}$ class extremely-low carbon bainite steel plate of the as-rolled type was developed making use of these features of the extremely-low carbon bainite microstructure. This new product has won an excellent evaluation for its extremely good weldability, shortening of lead times, and other advantages, and is enjoying increasing use, particularly in bridges. In addition, extremely-low carbon bainite weathering steel plates for welded structures, with atmospheric corrosion resistance for rural and coastal environments, and as-rolled steel plates with tensile strength increased to $690 \mathrm{~N} / \mathrm{mm}^{2}$ have also been developed, and practical application is progressing.

\section{Cold-rolling Strip, Surface Treatment}

\section{Starting Commercial Run of Continuous Pickling Line in Toyo Works By Nisshin Steel Co., LTD}

Nisshin Steel Toyo Works new Continuous Pickling Line has started Commercial Run since October 1st 1999.

This Pickling Line has world's first $\square$ Pre-descaling $\square$ function in pickling process for low carbon steel. HotRolling coils go to this mechanical descaling section prier to pickling section. Descaling efficiency is significantly improved by this $6 \mathrm{Hi}-\mathrm{UC}$ mill-descaler. Also Hot Rolling coil's surface and flatness are improved by $\mathrm{q}$ light rolling $\square$.

Moreover, we could save plant investment cost for pickling section and Hydrochloric Acid recovery plant by predescaling effect.

We established this world's first process based on development of rolling oil, strip shape and gauge control systems and disposal of fine scale.

This new pickling line is producing about 30000 tons/month and is extending product variety.

Sakai works No.1 Pickling Line (Started 1963) is shut down by replacement.

New Cold Rolling Mill (Constructing) will be connected with this pickling line in 2000 .

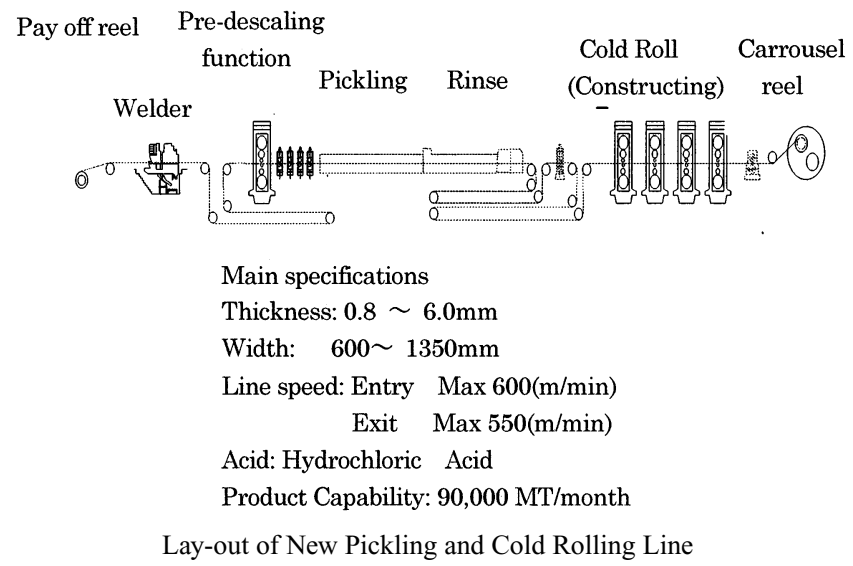




\section{Hot Dip Zn-Al-Mg Coated Steel $\square$ ZAM $\square$}

\section{By Nisshin Steel Co., LTD}

Nisshin steel developed new metal coated steel next to (1) Galvanized (2) Aluminized (3) $\mathrm{Zn}-\mathrm{Al}$ alloy. This new coated steel named $\triangle \mathrm{ZAM} \square$ is $\mathrm{Zn}-\mathrm{Al}-\mathrm{Mg}$ alloy coating steel and is developed in new CGL at Toyo works in Ehime pref.

Generally speaking Magnesium improves corrosion resistance of $\mathrm{Zn}$ coated steel.

However, technically speaking it is very difficult to stabilize several\% of Mg in coating layer. Nisshin steel succeeded to produce industrially new metal coated steel $\square$ ZAM which contain stabilized 3\% Mg in coating layer, based on development of coating bath contents, coating facilities and coating conditions.

ZAM has much better corrosion resistance compare to $\mathrm{Zn}$ coated steel due to synergy effect between Aluminum and Magnesium.

Also $\mathrm{Mg}$ in coating layer improves corrosion resistance for cutedge portion compare to $\mathrm{Zn}$ coating steel and $\mathrm{Zn}-\mathrm{Al}$ alloy coating steel. So ZAM have excellent corrosion resistance equal to 55\%Al-Zn (Galvalume). Moreover, scratch resistance of ZAM in forming process is better than the other metal coated steel due to harder coating layer.

According to the above reason, ZAM is very useful coated steel sheet for user.

Therefore, ZAM is suitable for structural usage of next generation's $\square$ long life steel house $\square$ mainly, agricultural, panels for road, automotive, electric appliances and other many industrial applications.

\section{High Formability-Anti Microbial Stainless Steel ¿NSS AM-4! By Nisshin Steel Co., LTD}

Nisshin Steel started to offer the new product which improve in living standard have interest in sanitation and environment.

Nisshin Steel pioneered a revolutionary $\square$ Copper $(\mathrm{Cu})$ deposition type ferritic stainless steel NSS AM-1 that boasts extraordinary corrosion resistance and anti microbial characteristics. And we also developed in same concept high quality austenitic stainless steel $\mathrm{NSSS}$ AM-3ם to expand lineup and to satisfy the diverse needs of users.

At this time Nisshin steel developed austenitic stainless steel $\square$ NSS AM-4ロ which has the same anti microbial as previous NSS lineup and is supplying deep drawing usage like as System kitchen sink.

Recently system kitchen has highly function. And material is needed high formability for sink usage. [NSS AM-4】 has enough $\square$ high formability $\square$ and $\square$ anti microbial $\square$ by original combination of contents.

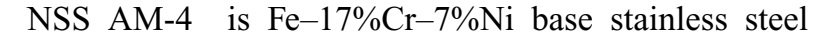
added $4 \%-\mathrm{Cu}$ and has same formability, season crack resistance as SUS304.

Nisshin steel developed anti microbial stainless steel which are added minute $\mathrm{Cu}$ particle by special heat treatment. Minute $\mathrm{Cu}$ particle is changed to $\square \varepsilon$ - $\mathrm{Cu}$ phase $\square$ in this process. Therefore, $\mathrm{Cu}$ can solve out easily and the stainless steel can keep anti microbial character continuously.

\section{Acknowledgments}

The author would like to acknowledge the assistance of the Technology Promotion Office, Iron and Steel Division of the Ministry of International Trade and Industry
(Economic climate of the iron and steel industry), as well as the guidance of The Japan Iron and Steel Federation (various statistics), major sustaining members of ISIJ, and the staff members of the ISIJ. 